\title{
A case of relapsing polychondritis mimicking lung cancer
}

\author{
Fatma CANBAY 1 \\ Aydın YILMAZ ${ }^{1}$ \\ Ayperi ÖZTÜRK ${ }^{1}$ \\ Zafer AKTAS ${ }^{1}$ \\ Ebru TATCI ${ }^{2}$
}

\footnotetext{
${ }^{1}$ Clinic of Inverventional Pulmonology, Ankara Ataturk Chest Diseases and Chest Surgery Training and Research Hospital, Ankara,Turkey

${ }^{1}$ Ankara Atatürk Göğüs Hastalıkları ve Göğüs Cerrahisi Eğitim ve Araştırma Hastanesi, Girişimsel Pulmonoloji Kliniği, Ankara, Türkiye

2 Division of Nucleer Medicine, Ankara Ataturk Chest Diseases and Chest Surgery Training and Research Hospital, Ankara, Turkey

${ }^{2}$ Ankara Atatürk Göğüs Hastalıkları ve Göğüs Cerrahisi Eğitim ve Araştırma Hastanesi, Nükleer Tıp Bölümü, Ankara, Türkiye
}

\section{SUMMARY}

\section{A case of relapsing polychondritis mimicking lung cancer}

Relapsing polychondritis $(R P)$ is a rare autoimmune disease, characterized by episodic inflammatory attacks on cartilaginous tissue. Elastic cartilage of the ears and nose, hyaline cartilage of the peripheral joints, vertebral fibrocartilage, tracheobronchial cartilage, and tissues rich in proteoglycan such as those in the eyes, heart, blood vessels, and inner ear are more likely to be affected. A 35-year-old male presented with complaints of hoarseness, tinnitus and dyspnea for 19 years, with a history of several diagnostic and therapeutic interventions for laryngeal and respiratory tract. He was diagnosed to have inflammation of the tracheobronchial cartilage, cardiac valvulopathy and conductive hearing loss after intensive diagnostic studies. He responded well to low-dose steroids in combination with methotrexate. RP is a diagnostically challenging condition and may cause significant morbidities during diagnosis. RP should be considered in differential diagnosis of airway obstruction as a rare condition.

Key words: Relapsing polychondritis, lung cancer, airway obstruction,

\section{ÖZET}

\section{Akciğer kanserini taklit eden tekrarlayan polikondrit olgusu}

Tekrarlayan polikondrit (TP); tekrarlayan kıkırdak doku inflamasyonu ile karakterize multisistemik bir hastalıktır. Kulak ve burnun elastik kıkırdağı, periferal eklemlerdeki hyalen kıkırdak, vertebral fibrokartilaj, trakeobronşiyal kıkırdak ile göz, kalp, damarlar ve iç kulaktaki proteoglikandan zengin yapılar etkilenebilir. Bu makalede 19 yıl önce boğulayazma sonrası başlayıp devam eden nefes darlı̆̆ı ile ses kısıklığı ve kulakta çınlama şikayetleriyle başvuran, trakeobronşiyal kıkırdak doku inflamasyonu, kardiak valvulopatisi ve iletim tipi işitme kaybı olan, düşük doz steroid tedavisine cevap veren 35 yaşında TP'li bir erkek olgu, endobronşiyal lezyonu taklit etmesinden ötürü sunulmuştur. TP, hava yolu obstrüksiyonunun ayırıcı tanısında nadir bir immünolojik neden olarak akılda tutulmalıdır.

\section{Yazışma Adresi (Address for Correspondence)}

Anahtar kelimeler: Tekrarlayan polikondrit, akciğer kanseri, hava yolu obstrüksiyonu

\section{Dr. Ayperi ÖZTÜRK}

Ankara Atatürk Gögüus Hastalıkları ve Gögüs Cerrahisi Eğitim ve Araştırma Hastanesi, Girişimsel Pulmonoloji Kliniği, ANKARA - TURKEY

e-mail: drayperi@yahoo.com 


\section{INTRODUCTION}

Relapsing polychondritis (RP) is a rare autoimmune disease, characterized by episodic inflammatory attacks on cartilaginous tissue. While its etiology is yet to be definitely outlined, IgG type antibodies against type 2 collagen are found in nearly half of all affected patients (1). Initially christened "polychondropathy" by Jacksh-Wartenhorst in 1923, the disease was later renamed as chondromalacia or chronic atrophic polychondritis. In 1960, Pearson et al. used the term "relapsing polychondritis" to describe a series of 12 cases that presented with clinical features that were characteristic of the disease (2). The incidence of RP is estimated to be around 3-5/ 1.000.000. The disease is not gender specific. While incidences of disease have been reported for every age group, it is more common in individuals in their 4 th and $5^{\text {th }}$ decades (1). Elastic cartilage of the ears and nose, hyaline cartilage of the peripheral joints, vertebral fibrocartilage, tracheobronchial cartilage, and tissues rich in proteoglycan such as those in the eyes, heart, blood vessels, and inner ear are more likely to be affected by this condition (3).

Herein, this case was reported to draw attention of physician that RP as a rare but significant immunological cause in differential diagnosis of airway obstruction.

\section{CASE}

A 35-year-old male patient consulted at our clinic with symptoms of dyspnea, hoarseness and tinnitus that started following an episode of near-drowning 19 years ago. He also had a history of respiratory arrest subsequent to a laryngeal biopsy 13 years ago, tracheostomy, several vocal cord biopsies for hoarseness (reported as inflammation), laryngeal dilation (seven times) and intermittent steroid use (longest time 1 year) for laryngeal problems. Physical examination revealed a tracheostomy scar on the cervical region and extensive keloid-like skin lesions on his entire body. Chest CT reported a lesion in the right vocal cord and a mass obliterating the left main bronchus. An endobronchial lesion at entrance of the left main bronchus was seen in fiberoptic bronchoscopy (FOB); biopsy results revealed the presence of inflammation. The patient was thus referred to our clinic for further diagnosis and evaluation of endobronchial treatment. 3D chest CT revealed heterogeneous soft tissue densities extending from the right paratracheal region to the carinal level.

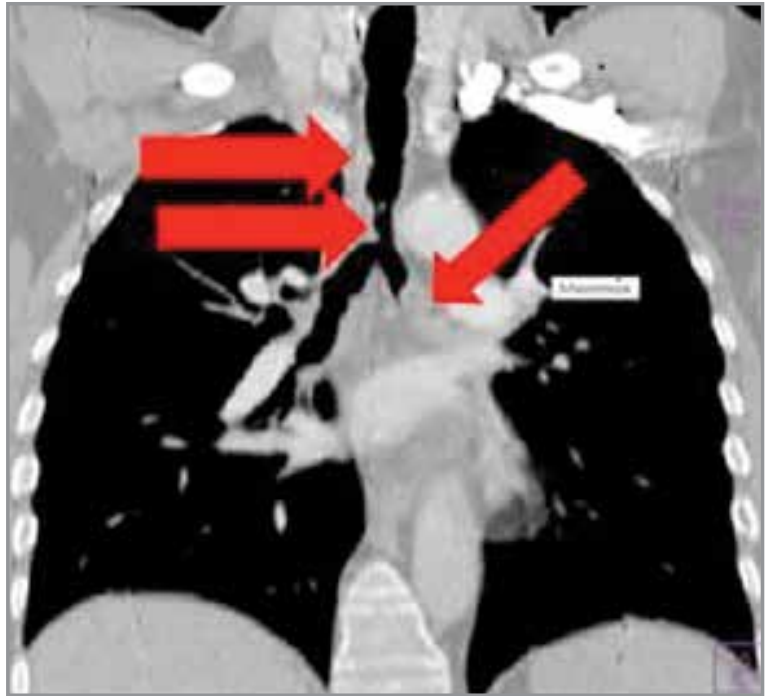

Figure 1. Soft tissue densities in tracheal lumen causing irregularities and nodular indentation (3D Chest CT).

This manifested as irregularities and nodular indentations in the tracheal lumen which were causing the narrowing of the trachea (Figure 1).

Conductive hearing loss was discovered when the patient was referred to an ear-nose-throat specialist for tinnitus. Echocardiography revealed a $2^{\text {nd }}-3^{\text {rd }}$ degree aortic regurgitation. With these clinical and radiology findings, a PET/CT scan, for probing the relapsing polychondritis, was considered to be imperative to the situation. PET/CT analysis revealed presence of soft tissue extending from the larynx to the right vocal cord along with thickening on the right lateral and anterior walls of the trachea till as far as the carina. This was causing constriction of the air column (SUVmax: 4, 25). Wall thickening on the left and right main bronchus was causing obliteration (SUVmax: 7, 53)(Figure 2).

Bronchoscopy was performed and soft lesions with a tendency to bleed were revealed. These tissues originated from the vocal cords and extended so as to encompass all tracheal cartilage prior to protruding into tracheal lumen and obliterating apertures of right and left main bronchus (Figure 3A,B). The specimen previously obtained at the referring center was analyzed also at our Pathology Department and inflammation was confirmed. In light of both clinical and radiological findings, the patient was diagnosed with relapsing polychondritis. 


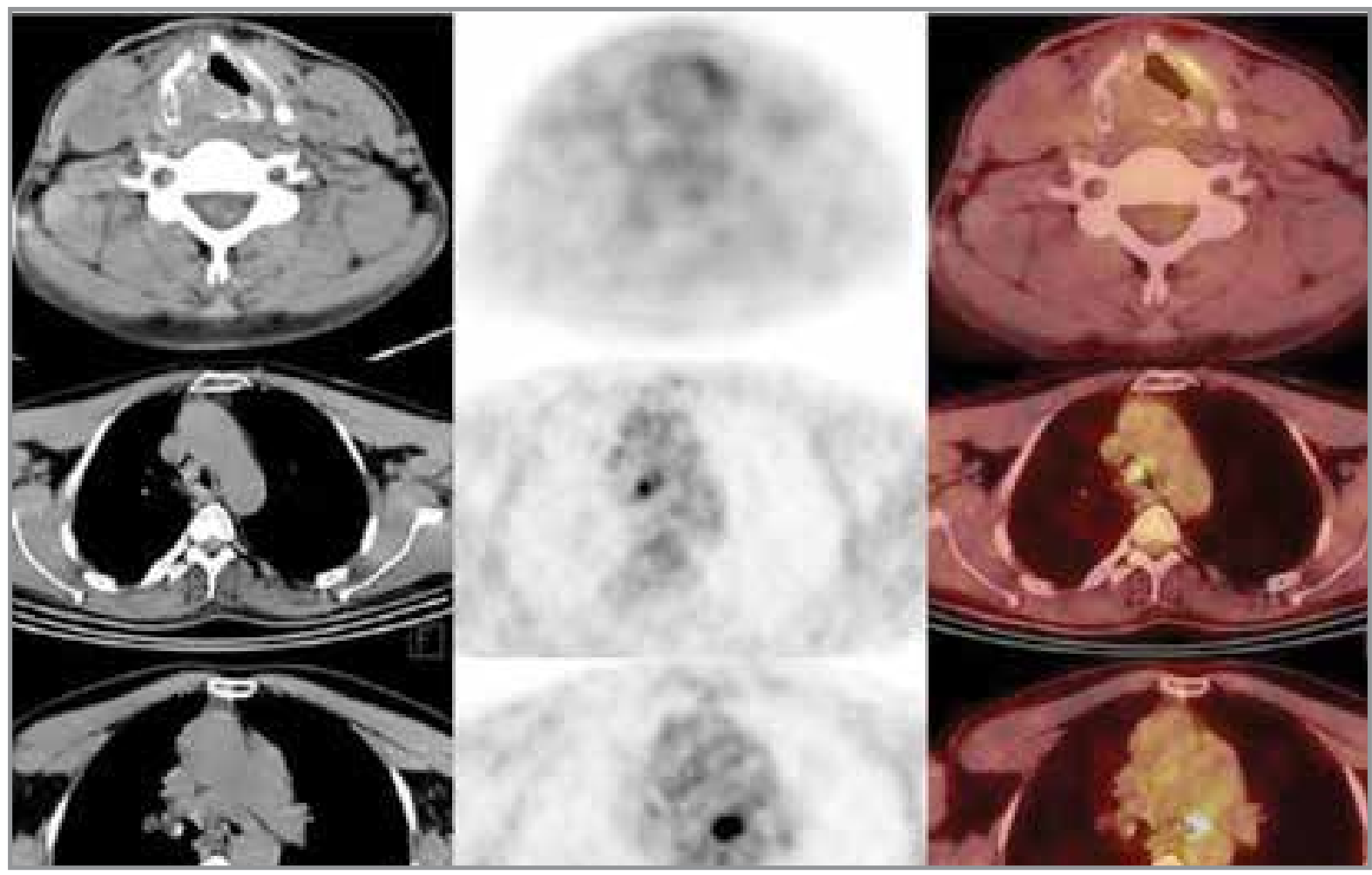

Figure 2. PET/CT images: Soft tissue in vocal cords without radiopharmaceutical accumulation (secondary to previous procedures), nodular wall thickening on trachea near the carina and left main bronchus.

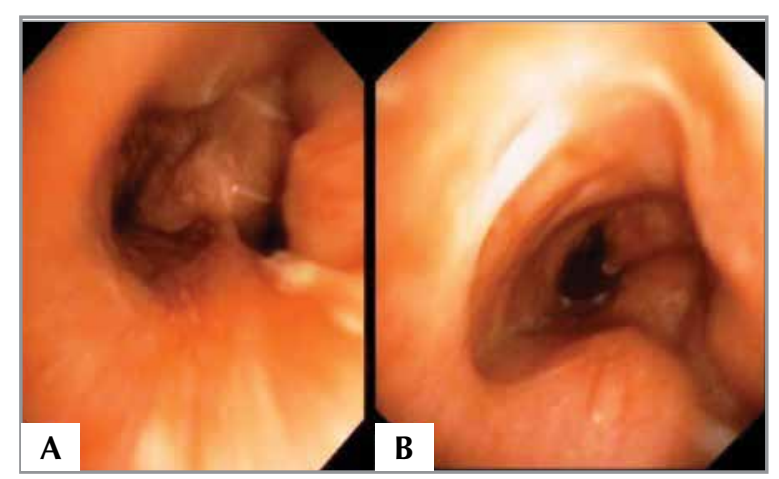

Figure 3. (A) Nodular irregularities on the right posterolateral and anterior walls beginning from the middle of trachea, (B) soft endobronchial lesions with a tendency to bleed, obliterating the apertures of right main bronchus (70\%) and left main bronchus $(80 \%)$.

\section{DISCUSSION}

Two of the most frequent findings in RP are auricular chondritis (95-90\%) and nasal chondritis (54-70\%). Vasculopathy or cardiac valvulopathy can be seen approximately in $30 \%$ of cases (4). In $50-75 \%$ of RP patients, recurrent, non-erosive, migratory arthritis and arthralgia that affects small and large joints can also be seen. Occasionally RP also presents with skin and central (sensorineural hearing loss) and peripheral nervous system involvements. This, however, is a relatively rare occurrence. Ocular inflammation is also known to occur. Renal involvement is rare but when present is associated with a negative prognosis (5). In $50-55 \%$ of the cases, the tracheal cartilage is affected and about $14 \%$ of cases present with respiratory tract symptoms. Most common symptoms observed when the respiratory system is involved are hoarseness, cough, wheezing, exertional dyspnea, and stridor. Mortality is $10-50 \%$ if there is laryngo-tracheobronchial tree involvement (3).

Echocardiography or cardiac MRI is recommended as a diagnostic tool for the demonstration of cardiac valvulopathy or aortic aneurism (1). Chest X-Ray are used to observed non-erosive arthropathy. Anterior and lateral airway wall thickening, and posterior membrane involvement is almost patognomonic. The most common CT finding is, as with our case too, thickening of the airway walls and fixed obstruction (6). Moreover, subglottic stenosis, tracheobronchial luminal narrowing, 
tracheal cartilage thickening accompanied by dense calcification, peripheral bronchial narrowing, and bronchiectasis can also occur. PET/CT scanning is useful for demonstrating multisystemic cartilage anomalies and for diagnosing RP (7).

Generally, the diagnostic criteria described by McAdam et al. are followed in order to diagnose RP (3). These are: 1- Relapsing chondritis in both auriculae; 2- Nonerosive inflammatory arthritis;3-Chondritis in nasal cartilage; 4-Eye inflammation including conjunctivitis, keratitis, scleritis, episcleritis and/or uveitis; 5-Chondritis in the upper respiratory tract involving laryngeal and/or tracheal cartilage; 6-Cochlear or vestibular dysfunction. The presence of three or more of the above mentioned conditions is considered as an affirmative diagnosis of RP. Damiani and Levine, and Michet et al. modified the McAdam criteria in 1979 and 1986 respectively $(8,9)$. These modified criteria are: 1-Presence of at least 3 or more McAdam criteria; 2-Presence of at least one or more McAdam criteria along with positive histopathology; 3-Chondritis in at least 2 different locations with patient exhibiting positive response to low-dose steroids or dapsone treatment. He was presented with extensive cartilage involvement from larynx to trachea, conductive hearing loss, valvulopathy, diffuse keloids, and response to low-dose steroids; in accordance with the modified McAdam criteria he was diagnosed with RP.

$\mathrm{RP}$ is associated with a $30 \%$ mortality rate and patient prognosis is variable. The most common cause of death is development of pneumonia secondary to airway anomalies and steroid use followed by airway collapse and cardiovascular complications. Early detection of respiratory system involvement is known to considerably reduce mortality $(3,8-10)$.

Disease management involves therapeutic intervention with immunosuppressants such as corticosteroids and dapsone. Additional medications also can be used along with steroids include antirheumatic drugs like azathioprine, anakinra, and abatacept; other supplementary drugs include cyclophosphamide, rituximab, tocilizumab, TNF- $\alpha$ inhibitors and colchicine. The best results were obtained with methotrexate and steroid combination (8-10). In our case, he had lowdose steroids in combination with methotrexate and responded well to treatment without any complication.

\section{CONCLUSION}

Even though RP is a comparatively rare disease, by virtue of its simultaneous attack on multiple systems, it has the potential to cause serious complications and mortality. As observed in our case, extensive laryngotracheal cartilage involvement can mimic endobronchial lesions leading to airway obstruction. Therefore, RP should be kept in mind as a rare but significant immunological cause in differential diagnosis of airway obstruction.

\section{REFERENCES}

1. Edrees A. Relapsing polychondritis: a description of a case and review article. Rheumatol Int 2011;31:707-13.

2. Pearson CM, Kline HM, Newcomer VD. Relapsing polychondritis. N Engl J Med 1960;263:51-8.

3. McAdam LP, O'Hanlan MA, Bluestone $R$, Pearson CM. Relapsing polychondritis: prospective study of 23 patients and a review of the literature. Medicine1976;55:193-215.

4. Adliff M, Ngato D, Keshavjee S, Brenaman S, Granton JT. Treatment of diffuse tracheomalacia secondary to relapsing polychondritis with continuous positive airway pressure. Chest 1997;112:1701-4.

5. Chang-Miller A, Okamura M, Torres VE, Michet CJ, Wagoner $R D$, Donadio $J \mathrm{Jr}$, et al. Renal involvement in relapsing polychondritis. Medicine (Baltimore) 1987;66:202-17.

6. Lee KS, Ernst A, Trentham DE, Lunn W, Feller-Kopman DJ, Boiselle PM. Relapsing polychondritis: prevalence of expiratory ct airway abnormalities. Radiology: 2006;240:565-73.

7. Deng H, Chen P, Wang L, Li X, Yi J. Relapsing polychondritis on PET/CT. Clin Nucl Med 2012;37:712-5.

8. Damiani JM, Levine HL. Relapsing polychondritis-report of ten cases. Laryngoscope 1979;89:929-46.

9. Michet CJ Jr, McKenna CH, Luthra HS, O'Fallon WM. Relapsing polychondritis. Survival and predictive role of early disease manifestations. Ann Intern Med 1986;104: 74-8.

10. Trentham $D E$, Le CH. Relapsing polychondritis. Ann Intern Med 1998;129:114-22. 